IADE-U

Anjoom Sataranjoom.satar@iade.pt

Márcia Gomes 09812@iade.pt

UNIDCOM/IADE

\title{
Portuguese Design History (1960-1974). Shaping the future: the role of the Art, Industrial Architecture and Industrial Design Nuclei of the National Institute of Industrial Research (I.N.I.I.)
}

There is a fundamental moment at the late 1950's in the Portuguese Design History: in a very singular context, the New State's Portuguese dictatorship, when the economy witnessed an improvement of its industrial sector which led to a first understanding by the government to promote Design in Portugal.

For that institutional recognition the National Institute of Industrial Research (I.N.I.I.), played a crucial role through one of its laboratories, the Art, Industrial Architecture Nucleus (later called Industrial Design Nucleus) that started its activities in 1960. This paper aims to present this case study in Portuguese Design History which is the subject of a research project that intends to provide a comprehensive understanding of the role played by the actions and actors of this Nuclei in the development of design in Portugal between 1960 and 1974, and how some players believed that a metadesign approach could contribute to the achievement of a democratic governance.

In order to interpret the State's constructed discourse on the articulation between design, the industry and its interaction with the public, according to techniques and methods used in the field of social science, such as surveys, classification and analysis of different kinds of documents, our study, simultaneously, intends to confront the state of design in Portugal with other countries, and cross-examine the dialogs developed, namely in relation to the European design reality. portuguese design, design histories, industrial policies, dictatorship's memories

\section{Introduction}

As a result of the economic demands of Post $2^{\text {nd }}$ World War, the Portuguese dictatorship was forced to give a wider attention to the industrial sector. The participation in the OECE reinforced the need for an economic plan, which led to the elaboration of the "Fomentation Plans". In the $2^{\text {nd }}$ Plan the transforming industry was elected and for the first time the industrial policies are assumed without ambiguity.

One of the dynamic efforts intended for the industrial sector was the establishment of the National Institute of Industrial Research which work began in 1959 with the mission "to promote, assist and coordinate research and assistance that interest the improvement and industrial development of the country". Inspired by models of European institutions 
like the Dutch T.N.O, (established by law in 1932), the I.N.I.I. answered to the Industrial Secretary and its main task was to provide scientific and technical assistance to private industries, according to the $2^{\text {nd }}$ Foment Plan.

In January 1960, Portugal joined EFTA that required an industrial reorganization and it was through the I.N.I.I. that the Government realized that investing in the quality of its industrial products, meant to promote design and its methods.

\section{The Art And Industrial Architecture Nucleus of the I.N.I.I.}

Whit this aim, still in 1960, the architect Teixeira Guerra, with the support of the I.N.I.I.'s director, engineer Magalhães Ramalho proposed a subject with enough potential to thrive with the relationship established between the Art and Technique subject matters. Teixeira Guerra initiated this proposal with the creation of the Art and Industrial Architecture Nucleus, which first activity was to develop aspects related to the designing of products, establishing a seminal industrial design sector.

One of Teixeira Guerra's first actions was to challenge architects Conceição Silva and Sena da Silva to visit Marinha Grande's manually crafted crystal factory, Stephens Brothers' Factory-School, and to evaluate the existing models, in order to achieve a greater rationality in production and thereby apply appropriate industrial design methods. Such actions led to the Art and Industrial Architecture Nucleus's public presentation in Lisbon's International Fair of 1962, with a stand designed by Sena da Silva and António Garcia².

In the early 6o's, the sculptress and glass designer Helena Matos, became responsible for the Nucleus and it was under her direction that the main actions were carried out.

These actions were developed by personalities either with training in architecture and fine arts from Lisbon and Oporto's Fine Arts Schools, or graduated from industrial and decorative arts schools inspired by the English and Austrian Arts and Crafts Schools, in virtue of "the not yet existing, in Portugal, schools that technically prepared, in structural terms, future professionals (...) - the "designers". What had been done was carried out by self-instructed artists, painters or draughtsman."3

Under the responsibility of Helena Matos, in 1965, the Nucleus organized the "1st Fortnight of Industrial Aesthetics" in Lisbon, with the realization of conferences lectured by European experts on industrial design, with the goal to discuss the problems of industrial design 4 .

This event was accompanied by an International Exhibition of Industrial Design which established a milestone in the Portuguese Design History: for the first time the English term design was integrated in the lexicon of the official discourse appearing in the title of the exhibition and its catalogue.

\footnotetext{
${ }^{2}$ Coutinho, Bárbara, coord. (2009). Sena da Silva. Lisboa: Fundação Calouste Gulbenkian, p. 72-73. 3 Arquitectura. Lisboa: $n^{\circ} 44$ (Setembro, 1952), p. 10-13 [Architecture. Magazine Lisbon: n. 44 (September, 1952), p. 10-13].

${ }^{4}$ Cf. Tradução das conferências proferidas durante a la Quinzena de Estética Industrial (1966). Lisboa: Instituto Nacional de Investigação Industrial, p. 1 [Translation of lectures given during the Ist Fortnight Industrial Aesthetics (1966). Lisbon: National Institute of Industrial Research, p. 1].
} 
We are dealing with one of the issues surrounding the dialects of design. Under the influence of the French culture, which in 1950 ruled the action of Jacques Viénot, creator of the association and magazine Esthétique Industrielle, this French terminology was adapted by the Portuguese discourse and used even in the 6o's.

The fact that the English expression Industrial Design appeared in the title of the exhibition and its catalogue created a turning point in the official discourse in relation to the French terminology, considered outdated by the young Portuguese creators who collaborated with the Nucleus and it tackled an era when design activities launched from Art and Crafts to industrial production.

This change has to be understood in relation with the Intercalary Fomentation Plan (19651967) that emphasized the need to review the industrial conditioning. The dictatorship sought to modernize and Portuguese creators took advantage of the little openness that was provided.

The International Exhibition of Industrial Design performed in June, at the Foz Palace (Lisbon), presented industrial design pieces from European countries (England, France, Italy, Finland) and some national, with a concern, quoting engineer Magalhães Ramalho, "to make accessible to all officers, technicians and artists the most modern ideas and work processes that interest the progress and expansion of industrial activities and about the most important and increasing current problem of industrial design"5.
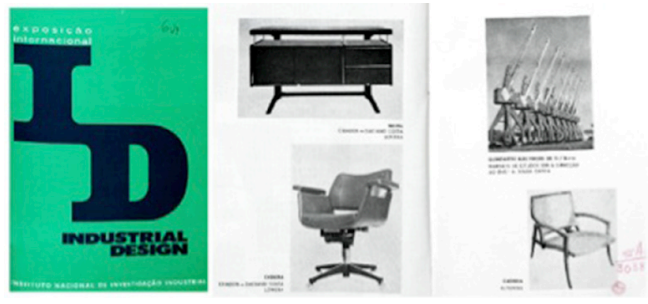

Figure 1.

Cover and pages of the International Exhibition of Industrial Design catalogue with the Portuguese products (1965)

Succeeding the $1^{\text {st }}$ Fortnight of Industrial Aesthetics, in 1966 and 1967, the I.N.I.I.'s Art and Industrial Architecture Nucleus promoted courses in complementary fields for the subject of industrial design, having two of the lecturers of the Fortnight, the architect and designer Sergio Asti and the colour expert Xavier Auer.

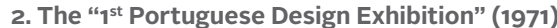

In 1971, in a context of some open politics (period commonly referred as Marcelista "Spring"6), Helena Matos organized another project: under the leadership of the engineer Torres Campos, the second Director of the I.N.I.I., they accomplished the " $1^{\text {st }}$ Portuguese Design Exhibition".

${ }_{5}^{5}$ Tradução das conferências proferidas durante a la Quinzena de Estética Industrial (1966). Lisboa: Instituto Nacional de Investigação Industrial, p. 1 [Translation of lectures given during the Ist Fortnight Industrial Aesthetics (1966). Lisbon: National Institute of Industrial Research, p. 1].

${ }^{6}$ Means the initial period between 1968 and 1970 of the government of Marcelo Caetano (chosen to succeed Salazar), which operated a moderate political liberalization, creating the expectation of a real reform of the Portuguese regime, which failed to happen. 
theme 2

memory

Figure 2.

Overview of the $1^{\text {st }}$ Portuguese Design Exhibition, Stock Exchange building, Oporto, November, 1971. strand 1

design histories: tradition, transgression and transformations

The proposal for this Design Exhibition was initially made by the painter and designer Cruz de Carvalho and the designer João Constantino, through Interforma their furniture company. The support of the I.N.I.I. gave a new dimension to the original draft, which turned out to have the sponsorship of the Export Promotion Fund, the Portuguese Industrial Association and Longra Metallurgy.

This last company, knows a strategy of corporate design thanks to the action of the entrepreneur Fernando Seixas, who invited the painter and designer Daciano da Costa to be the consultant and designer for metal office furniture, a strong relation that would extend for three more decades until the early 9o's. The first models of office furniture that he designed for Longra, were "Prestígio", line created in 1962 (which became a market success) and "Cortez", the first to combine wood with metal, both contributed to the renewal of the Portuguese office furniture market, offering a formal modernity that until then was almost non-existent.

The mentioned models designed by Daciano for Longra had impact in the various exhibitions accomplished by the Nuclei, like in the "1 $1^{\text {st }}$ Portuguese Design Exhibition".

Held in March 1971 at FIL, the main goal of this exhibition was to bring together the work that best represented the state of art in design in Portugal, for which included the presentation of sixty-seven designers with two hundred and sixty products. In the exhibition's catalogue, the Nuclei established design as a "democratization of usefulpleasant, useful-comfortable that is no longer a privilege for a few" making it "accessible to the general public"7. In November, this exhibition had a second presentation in the city of Oporto, at the Stock Exchange building which iron and glass structure, welcomed the display of the Portuguese design products.

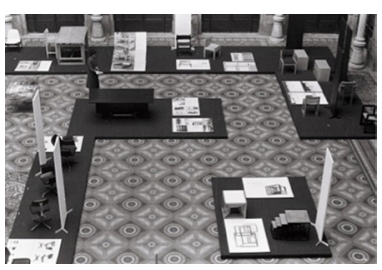

\section{Industrial Design Nucleus: The “2nd Portuguese Design Exhibition” (1973)}

Following this $1^{\text {st }}$ Exhibition, the Art and Industrial Architecture Nucleus finally changed to Industrial Design Nucleus with Helena Matos as leader and, in 1973 the Nucleus organized the " 2 nd Portuguese Design Exhibition".

Once again, this Exhibition was shown at the FIL in March 1973, conducted by the Nuclei, conceived and directed by Sena da Silva and the Cooperative "Praxis". As a result of this display, the design in Portugal finally began to have a larger public recognition and ceased to be understood as a simple embellishment of the product, but as a projectual subject that ensures the quality concept of industrial products, confirmed by the large number of stands and through the attention given by the general and specialized press.

$\left.7\right|^{a}$ Exposição de Design Português (1971). Lisboa: Instituto Nacional de Investigação Industrial, 115 [1St Portuguese Design Exhibition (1971). Lisbon: National Institute of Industrial Research, p. 115]. 
Sena da Silva and the Cooperative "Praxis" invited experts in different areas of design hoping that their contributions would prevent misreadings about a profession often associated to superficial aspects related to ephemeral trends.

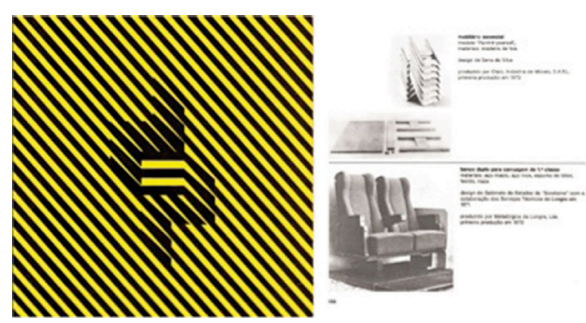

\section{Conclusion}

In relation to design produced in Portugal and exposed between 1965 and 1973, we underline the influence of Modern Design since the Bauhaus principles to the influences of system-design established in the early 6o's by designers as Hans Gugelot from Hochshule für Gestaltung ( $\mathrm{HfG}$ ), at Ulm, pedagogic concepts and design principles that inspired and motivated our designers during this decades ${ }^{8}$.

Also the influence of Scandinavian and Italian design have been felt, as observed in the glasses designed by Carmo Valente or Helena Matos and, in the second case, it is visible the influence of Gio Ponti design at the "Cortez" line of Daciano?.

Furthermore worth pointing out the contributions related to the work of industrial design linked to former colonies: in these decades the largest markets for the Portuguese design were the territories of Angola and Mozambique. Companies like Longra and ADICO (based in the city of Aveiro) exported in large-scale tubular metal furniture to equip schools, hospitals, offices that we can still find in some of this type of buildings. This is a line of research that needs to be continued in future projects that we expect to be developed.

\section{References}

Bürdek, B. E. (2005). Design: History, Theory and Practice of Product Design. Basel, Boston, Berlin: Birkhäuser Verlag.

Costa, D. \& Souto, H. (1993). Frederico George. Ver pelo Desenho. Lisboa: Livros Horizonte/C.M.L.

Coutinho, B., coord. (2009). Sena da Silva. Lisboa: Fundação Calouste Gulbenkian. Lees-Maffei, G., Houze, R. (2010). The Design History Reader. Oxford \& New York: Berg Publishers.

Nunes, G. (2012). O mobiliário português de produção em série do terceiro quartel

\footnotetext{
${ }^{8}$ The "Artistic Training Course" programmed in 1965 by the art historian José-Augusto França, in collaboration with SNBA board of directors (then chaired by Francisco Conceição Silva) is representative of this influence, stating that it relies on knowledge and reflection "of modern German teaching experiences" (Hochschule für Gestaltung program, Ulm)". Cf. Souto, Helena - História do Design em Portugal I. Reflexões. Lisboa: IADE Edições, 2009, p. 84.

${ }^{9}$ Nunes, Graça (2012). O mobiliário português de produção em série do terceiro quartel do século XX (1951-1974). Lisboa: Tese de Doutoramento em Design, Faculdade de Arquitectura, vol. 1, p. 103.
}

Figure 3.

Cover and pages of the $2^{\text {nd }}$ Portuguese Design Exhibition (1973) catalogue - at the top, Sena da Silva's chair and table (1973) produced by Olaio, furniture industry. At the bottom, double seat for a $1^{\text {st }}$ class railway carriage (1972) developed and produced by the metallurgy enterprise Sorefame 
do século XX (1951-1974). Lisboa: Tese de Doutoramento em Design, Faculdade de Arquitectura, 2 vols.

Souto, H. (2000). 100 Anos de Design Português. O tempo do Design. Anuário 2000. Lisboa: Centro Português de Design, 8 (21).

Souto, H. (2009). História do Design em Portugal I. Reflexões. Lisboa: Edições IADE. Woodham, J. M. (1997). Twentieth-Century Design. Oxford University Press.

\section{Primary Sources}

Arquitectura. Lisboa: $\mathrm{n}^{\circ} 44$ (Setembro, 1952).

"Decreto n. ${ }^{\circ}$ 42.121: Promulga o Regulamento do Instituto Nacional de Investigação Industrial." Diário do Governo, I Série - No 19 (23 de Janeiro), 1959, p. 71-74. Exposição Internacional de Industrial Design (1966). Lisboa: Instituto Nacional de Investigação Industrial.

$7^{a}$ Exposição de design português (1971). Lisboa: Instituto Nacional de Investigação Industrial.

$2^{a}$ Exposição de design português (1973). Lisboa: Instituto Nacional de Investigação Industrial.

Presidência da República: Lei n. ${ }^{\circ}$ 2089: Promulga as bases para a criação, no Ministério da Economia, do Instituto Nacional de Investigação Industrial." Diário do Governo, I Série - No 133 (8 de Junho), 1957.

Tradução das conferências proferidas durante a I Q Quinzena de Estética Industrial (1966). Lisboa: Instituto Nacional de Investigação Industrial.

Acknowledgments: This paper presents an overview of a research project cofunded by the FCT (Foundation for Science and Technology) and COMPETE, PTDC/EAT-HAT/121601/2010 Design in Portugal (1960-1974): the actions, actors and repercussions of the Art, Industrial Architecture and Industrial Design Nuclei of the National Institute of Industrial Research (I.N.I.I.), which we thank the support because without it, wouldn't be possible to advance in the Portuguese Design Studies. 